УДК 739.2:745.55

DOI https://doi.org/10.32782/facs-2021-2-6

\title{
Софія ТРИКОЛЕНКО
}

кандидат мистецтвознавства, старший викладач, Національний авіаиійний університет, пр. Гузара Любомира, 1, м. Киї, Україна, 03058

ORCID: 0000-0003-2766-8345

Бібліографічний опис статті: Триколенко, С. (2021). Природні форми мінералів у ювелірній творчості Андрія Комарова. Fine Art and Culture Studies, 2, 44-48, doi: https://doi.org/10.32782/facs-2021-2-6

\section{ПРИРОДНІ ФОРМИ МІНЕРАЛІВ У ЮВЕЛІРНІЙ ТВОРЧОСТІ АНДРІЯ КОМАРОВА}

\begin{abstract}
Стаття пропонує читачам ознайомитися з однією з найціікавіших тенденцій сучасного ювелірного мистеиттва - використанням мінералів природних форм із мінімальною обробкою. Протягом багатьох століть натуральні форми кристалів нівелювалися, руйнувалися внаслідок огранки та надання їм стандартних силуетів. У статті наводяться приклади перснів молодого українського ювеліра Андрія Комарова, під час створення яких майстер спирався на гармонію природних форм, структур і забарвлення, підбираючи до них оправи, які б найкраще доповнювали вставки, при иъьому не заважаючи їх сприйняттю глядачем. Митець використовує одну з найдавніших ювелірних технік - філігрань, створюючи художньо досконалі композиції, які розкривають природний потенціал обраних мінералів. Розглядаються різні варіанти перснів на основі однакових матеріалів.

Ключові слова: ювелірне мистецтво, мінерал, камінь, перлина, Андрій Комаров, філігрань, природна форма, необроблені камені, перлини, срібло.
\end{abstract}

\section{Sofia TRYKOLENKO}

Candidate of Art Criticism, Senior Lecturer, National Aviation University, Husar Lubomyr Ave., 1, Kyiv, Ukraine, 03058

ORCID: 0000-0003-2766-8345

To cite this article: Trykolenko, S. (2021) Pryrodni formy mineraliv u yuvelirnii tvorchosti Andriia Komarova [Natural forms of minerals in jewelry by Andry Komarov]. Fine Art and Culture Studies, 2, 44-48, doi: https://doi.org/10.32782/facs-2021-2-6

\section{NATURAL FORMS OF MINERALS IN JEWELRY BY ANDRY KOMAROV}

This article offers readers to get acquainted with one of the most interesting tendencies in contemporary jewelry artthe use of minerals of natural forms, with minimal interference of processing. For many centuries, the natural forms of crystals were leveled, destroyed as a result of the cut and give them standard silhouettes. The article gives examples of the rings of the young Ukrainian jeweler Andriy Komarov, during the creation of which the master was based on the harmony of natural forms, structures and colors, selecting the settings that would best complement the inserts, without interfering with their perception by the viewer. The artist uses one of the oldest jewelry techniques - filigree, creating artistically perfect compositions that reveal the natural potential of selected minerals. Different variants of the solution of rings on the basis of identical materials are considered. He works with the most diverse forms, colors and structures of minerals, he often uses filigree techniques. Extreme talent and high artistic taste give birth to unique concepts of products in which all elements are subject to a single, coherent design; and the plan, in turn, is based on the shape, structure, color and texture of the selected mineral. The master jeweler develops a sketch based on existing material, creating for him an ideal framework. The ornaments of Andrei Komarov are full members of the jewelry composition: they not only hold the inserts, they complement them, contrast them, effectively shade or interweave into a single synthesis, repeating the silhouette or structural lines of minerals.

Key words: jewelry, mineral, stone, pearl, Andriy Komarov, fligree, natural form, rough stones, pearls, silver.

Постановка проблеми. Безмежне розмаїття сучасних прикрас зумовлює актуальність дослідження нових художніх засобів, стилів, технік, матеріалів і принципів комбінування матеріалів.
Початок XXI століття відзначається посиленням уваги до натуральних, необроблених форм мінералів, які використовуються самостійними майстрами та залучаються до колекцій відо- 
мих світових ювелірних брендів. Унікальність природних силуетів, структур і забарвлення мінералів робить їх досконалим шедевром стихій світобудови, тому метою багатьох митців $€$ виявлення їхньої краси з мінімальною обробкою. Наразі огляд, систематизація досвіду художників-ювелірів у царині створення прикрас із мінералами природних форм набувають великої актуальності, оскільки це має значення не лише для теоретичного мистецтвознавства, а й для гемологічної та геологічної науки. Формування нової тенденції оброблення мінералів, що мінімізує втручання у форму, структуру й забарвлення, вже поширюється серед представників природничих і технічних спеціальностей. Виховання нової генерації художників, дизайнерів й майстрів, які базуватимуться безпосередньо на вже створених природою мінеральних шедеврах, є актуальною проблемою для теоретичних праць сьогодення.

Аналіз досліджень. Дослідження сучасних тенденцій в українському ювелірному мистецтві, використання новітніх матеріалів і художніх мов знаходять виявлення в поодиноких працях українських дослідників, критичних відгуках i оглядових статтях. Зокрема, становлення вітчизняних ювелірних шкіл на базі державних учбових закладів і авторських майстерень протягом другої половини XX століття розглядають Л. Пасічник (Пасічник, 2012), 3. Чегусова (Чегусова, 2002) і О. Роготченко (Роготченко, 2013: 117-127). Безпосередньо сучасним митцям присвячені статті О. Росинської (Росинська, 2009: 102-110), С. Триколенко (Триколенко, 2017: 46-49).

Метою статті $\epsilon$ вдосконалення роботи сучасних майстрів-ювелірів, стимулювання та заохочення їх до використання необроблених мінералів шляхом ознайомлення читачів з уже наявними прийомами використання мінералів природних форм у ювелірному мистецтві. У якості прикладів наводяться персні українського ювеліра Андрія Комарова, творчість якого досконало розкриває красу мінімально оброблених мінералів. Пропонуються до розгляду різні варіанти виробів з однакових матеріалів.

Виклад основного матеріалу. Розглядаючи творчість вітчизняних ювелірів сьогодення, хочеться відзначити багатогранність авторських трактувань традиційних технік, розмаїття новітніх прийомів і матеріалів, а також оригінальність сюжетів. Зокрема, великою увагою майстрів початку XXI століття користуються природні форми мінералів, які піддаються мінімальному обробленню або ж не обробляються зовсім. Милування природними формами мінералів набуло особливого поширення в усьому світі на межі XX - XXI століть, саме в цей період виникають численні авторські майстерні, які обирають такі мінерали як основний матеріал. Те, що протягом століть вважалося (і продовжує вважатися у великих ювелірних компаніях) недоліком (кольорові вкраплення, структурні включення, поєднання кількох різних мінералів в одній кристалічній формі чи групі, асиметричність, химерність форми), стає перевагою для одиничних авторських виробів. Проте навіть у колекції відомих світових брендів проникають натуральні форми мінералів; так, Chanel, Сільвія Толедано, Elia Saab i Calvin Klein активно доповнюють свої колекції виробами з необробленими вставками. Повертаючись на українські терени, хочеться докладно розглянути вироби Андрія Комарова, який часто звертається саме до необроблених форм вставок. Андрій Комаров працює 3 найрізноманітнішими за формами, кольорами та структурами мінералами, найчастіше використовує техніку «філігрань». Неабиякий талант і високий художній смак породжують унікальні концепції виробів, у яких всі елементи підпорядковані єдиному цілісному задуму, а задум грунтується на формі, структурі, забарвленні й фактурі обраного мінералу. Майстерювелір розробляє ескіз, відштовхуючись від уже наявного матеріалу, створюючи для нього ідеальну оправу. Оправи прикрас Андрія Комарова $є$ повноцінними учасниками ювелірної композиції: вони не просто утримують вставки, вони доповнюють їх, контрастують із ними, ефектно відтіняючи, або ж переплітаються в єдине ціле, повторюючи силуетні чи структурні лінії мінералів. У статті ми пропонуємо розглянути персні зі вставками мінералів природних форм. Така форма ювелірної прикраси, як перстень, має тисячолітню історію й поєднує в собі потужну сакральну, захисну та суто декоративну функції. Традиції створення перснів пройшли чимало етапів і налічують безліч прийомів художнього й практичного втілення авторських задумів. Андрій Комаров, базуючись на формі й структурі 
обраного мінералу, відповідно до них розробляє концепцію оправи, формуючи iï з чітких геометрично правильних ліній або ж навпаки, створюючи складний орнамент хаотичного, ліаноподібного мережива, яке огортає вставку, немов стебла плюща - гірське каміння. У виробах майстра оправи стають доповнюючим, композиційно незамінним елементом, який виконує не лише суто функціональну, а й важливу художньо-смислову функцію. Огляд виробів варто розпочати із серії перснів з азуритом; унікальна природна структура, фактура й забарвлення роблять азурит одним із найцікавіших каменів для ювелірного мистецтва. Тендітність внутрішньої кристалічної будови та складна кольорова розтяжка роблять мінерал подібним до об’ємного космічного пейзажу. Оправи всіх перснів максимально відкривають вставку, утримуючи іiі лише за допомогою кількох дужок: майстер максимально зосереджує увагу глядачів на красі обраного мінералу, намагаючись не перекривати його лініями металу. Кільця формуються з хаотичного переплетення срібних дротів, які нагадують блискуче павутиння. Фантазія майстра створила вироби, які можна потрактувати і як земні квіти, і як космічні вибухи наднових зірок. Таку ж шорстку поверхню має малахітова вставка перснів із серії «Африканська мрія», що демонструють красу не лише неограненої форми кристалу, a i його природної невідполірованої фактури. Саме матова поверхня найбільш повно розкриває красу забарвлення каменю - кольори здаються особливо насиченими, тональні перепади - найбільш контрастними. Обидва персні мають ажурні срібні оправи, доповнені чорнінням. У першому персні вставка утримується невеликими дужками 3 декоративними завитками, у другому - масштабними дужками 3 внутрішнім ажурним декором. Холодний блиск срібла із затемненими чорнінням глибинами утворює разючий контраст 3 яскравими кольорами каменів, посилюючи емоційне сприйняття виробу. Наступний запропонований до розгляду виріб - перстень із кристалом турмаліну в срібній оправі із золотим декором. Унікальне темно-рожеве забарвлення кристалу згущується до середини, краї залишаються більш прозорими. Природна форма нагадує піраміду зі скошеною верхівкою; світло, пробиваючись крізь товщу кристалу, підсвічує вну- трішні грані. Оправа в цьому виробі $є$ повноцінним композиційним елементом: дужки оформлені у вигляді листків трилисника, кільце оздоблене ажурними лініями, які нагадують стебла рослин. Художня концепція персня заглиблює глядачів у бурхливий світ природи й прадавніх легенд, адже квітки конюшини фігурують в епосах різних народів світу, їм приписують цілющі властивості. Ще один перстень із яскраво-рожевим турмаліном у срібній оправі, виконаний у техніці філігрань, отримав назву «В обіймах пристрасті». Асиметричний кристал має гладко відполіровану поверхню, проте силует залишився натуральним, без втручання огранки. Дужки оправи не мають чіткої форми, проте доповнені тонкими срібними дротами, декоративно закрученими в серединах кріплення. Оправа оформлена аналогічно до попереднього виробу. Перстень із кристалом аквамарину в срібній із золотом оправі можна віднести до найоригінальніших виробів майстра: він має складну форму центрального сегмента, оправа доповнюється численними декоративними елементами. Художня концепція демонструє цілий пейзаж: призмоподібна видовжена форма кристалу, його ніжноблакитне забарвлення нагадують чисту воду стрімкої гірської річки. Оправа утримує камінь 3 усіх боків, максимально відкриваючи верхню площину й бокові грані. Декор оправи відтворює авторський філософський задум: із двох боків камінь утримують срібні хвилі, довкола оправи лінії нагадують стрімкі скелі та гірську рослинність. Для посилення контрастності використано позолоту - окремі елементи оправи сяють золотом, а заглиблення здаються особливо темними, як глибокі урвища. Поєднання пласких деталей з об'ємними підкреслює розмаїття дикої природи - гладка поверхня скель чергується з високою рослинністю, дрібні квіти пробивають собі дорогу крізь камінь... Велике значення має освітлення: хоча камінь не просвічується 3 усіх боків, його верхня й частково бокові грані відкриті, таким чином світло підсвічує внутрішню структуру кристалу (Триколенко, 2017: 48). Персні з барочними перлинами демонструють красу унікальних форм барочних перлин, які протягом століть вважалися дефектними й практично не використовувалися в ювелірному мистецтві. Саме їхня химерність, численні нерівності зумовлюють найбільшу унікальність, адже завдяки таким 
силуетам перламутр нерівномірно розповсюджений на поверхні, унаслідок чого перлина містить різні тональні перепади та кольорові вкраплення, подібні до муару. Зокрема, перстень «Морське чудовисько», вставкою якого є велика біла барочна перлина, виконаний у вигляді скрученого морського змія. Срібна оправа має таку ж нерівну та химерну форму, як і вставка: з одного боку вона пластиноподібна, доповнена невеликою перламутровою деталлю, а з іншого виведена в кілька дужок, які утримують перлину. Форма кільця - пряма, його поверхня гладенька й де-не-де оздоблена гравіюванням. Натомість кільця двох перснів із чорними перлинами оформлені у вигляді хаотично переплетених дротів, які переходять у мінімізовану оправу - утримують вставки 3 кількох боків, спираючись на нерівності рельєфу перлин. Перстень «Блакитна мрія» 3 бірюзою здається мініатюрним порівняно 3 іншими, кільце має чіткий симетричний орнамент. Вставка - невелика бірюза насиченого кольору 3 чорними вкрапленнями, які надають поверхні ефект кракелюру. У цьому разі вставка сама по собі є контрастним, композиційно наповненим й змістовно довершеним елементом, який не потребує масштабної оправи або ж додаткового декорування дужок. Перстень із хризоколою має схильну до симетрії композиційну будову: iз двох боків його утримують однакові срібні дужки, розміщені на однаковій відстані. Знизу камінь підхоплюють стилізовані під рослинні стебла дроти. Кільце оформлене ажурним срібним мереживом, сформованим кількома симетричними завитками. Унікальність мінералу, його яскраве кольорове насичення, багатство палітри, витончені природні орнаменти концентрують увагу глядачів безпосередньо на вставці. Як у попередньо розглянутому персні 3 бірюзою, камінь виступає самостійним композиційним центром, який завдяки мінімалізму оправи не має змістовної противаги. Абсолютно протилежний принцип задіяний у срібному персні із зеленим турмаліном. Оправа виступає повноцінним композиційним елементом на одному рівні зі вставкою. Кристал турмаліну має порівняно невеликі розміри, його 3 двох боків, перпендикулярно до фаланги пальця, утримують симетричні кільця, доповнені пружиноподібними декоративними деталями.
Кільце оздоблене хвилястими лініями зі срібного дроту. Шорстка фактура каменю становить контраст до гладкої поверхні відполірованих елементів оправи, а часткова прозорість кристалу дозволяє срібній основі просвічуватися крізь насичену зелень турмаліну, посилюючи ефект глибини. Протилежні принципи виконання оправ демонструють два персні 3 хризолітом. Трав'янистозелений колір мінералів і їхнє нерівномірне забарвлення підкреслюють глибини шорсткої фактури, роблячи відблиски особливо насиченими, а глибини - затемненими. Оправа персня «Лісове дерево» досить масштабна й виведена до каменю гострими, рівномірними шипами, які нагадують колючки. Натомість кільце оформлене хаотичними ліаноподібними лініями. Оправа персня «Лісовий дух» ескізно цілісна, усі лінії кільця й оправи плавні, заокруглені та розміщені асиметрично, мов зарості плюща в лісових хащах. Розглянувши деякі персні Андрія Комарова, можна стверджувати, що майстер досконало розкриває потенціал природних форм мінералів, а також вдало використовує їхні невідполіровані поверхні. Також варто відзначити й те, що він чудово підбирає всі композиційні складники виробу, масштаби вставки, оправи й кільця не суперечать один одному, утворюючи єдине цілісне гармонійне поєднання.

Висновки. Унікальні природні форми мінералів презентують їх як довершений елемент ювелірного виробу. Використання мінералів природних форм набуває все більшої популярності в усьому світі, і це стимулює розвиток художнього мислення та творчих пошуків митців, які грунтуються на принципі попереднього підбору матеріалів, подальше розроблення концепції виробу. У статті наведені приклади принципово відмінних концепцій однотипних виробів, які демонструють можливості використання необроблених або частково оброблених мінералів. Андрій Комаров - представник нової генерації вітчизняних ювелірів, він працює 3 найрізноманітнішими матеріалами й типами прикрас. Приклади його робіт утілюють кращі аспекти ювелірного мистецтва, у якому досконалий природний матеріал диктує форми майбутніх виробів, а не навпаки, а отже, такі вироби служать взірцем для майбутніх поколінь митців. 


\section{ЛIТЕРАТУРА:}

1. Пасічник Л. Ювелірне мистецтво України в контексті художнього процесу останньої чверті XX - початку XXI століття (за матеріалами виставок Києва). Інститут мистецтвознавства, фольклористики та етнології НАН України. 2012. URL: http://um.etnolog.org.ua/zmist/2012/27.pdf.

2. Чегусова 3. Декоративне мистецтво України кінця XX століття. 200 імен. Київ: Атлант ЮЕмСi, 2002. 511 с.

3. Роготченко О. Ювелірне мистецтво України XX сторіччя: Особливості розвитку. Сучасне мистецтво. 2013. Вип. 9. С. 117-127.

4. Росинська О. Сучасне ювелірне мистецтво Буковини. Образотворче мистецтво. 2009. № 3. С. 102-103.

5. Триколенко С. Краса природних форм мінералів у ювелірних виробах Андрія Комарова. Збірник матеріалів міжнародної науково-практичної конференції «Сучасні технології та особливості видобутку, обробки і використання природного каміння», 23-24 листопада 2017 року, Київ, Україна. Київ: Державний гемологічний центр України, 2017. С. 46-49.

\section{REFERENCES:}

1. Pasichnyk L. Yuvelirne mystecztvo Ukrayiny v konteksti xudozhnogo procesu ostannoyi chverti XX - pochatku XXI stolittya (za materialamy vystavok Kyeva) [Jewelery art of Ukraine in the context of the artistic process of the last quarter of the XX - the beginning of the XXI century (based on the materials of Kyiv exhibitions)] [Institute M. T. Rylskyy of study of art, study of folklore and ethnology of the National Academy of Sciences of Ukraine], 2012. URL: http://um.etnolog.org.ua/zmist/2012/27.pdf. [in Ukrainian].

2. Chegusova Z. Dekoraty'vne my'stecztvo Ukrayiny' kincya XX stolittya. 200 imen [Decorative art of Ukraine of the end of XX century. 200 names]. Kyiv: Atlant YuEmSi, 2002. 511 p. [in Ukrainian]

3. Rogotchenko O. Yuvelirne mystecztvo Ukrayiny XX storichchya: Osoblyvosti rozvytky [Jewelery Art of Ukraine of the XX Century: Features of Development] Modern Art, 2013,Nr. 9. Pp. 117-127 [in Ukrainian]

4. Rosy'ns'ka O. Suchasne yuvelirne mystecztvo Bukovyny [Contemporary jewelry of Bucovina], 2009, Nr 3. Pp. 102- 103 [in Ukrainian]

5. Try'kolenko S. Krasa pry'rodny’x form mineraliv u yuvelirny'x vy'robax Andriya Komarova [Beauty of natural forms of minerals in jewelry of Andriy Komarov] Modern technologies and features of extraction, processing and use of natural stones. Kyiv: State Gemological Center of Ukraine, 2017, pp. $46-49$ [in Ukrainian] 